\title{
Wedge Excision
}

National Cancer Institute

\section{Source}

National Cancer Institute. Wedge Excision. NCI Thesaurus. Code C51690.

Surgical removal of a triangular wedge shaped section of tissue. 